\title{
СИСТЕМА ОХОРОНИ ЗДОРОВ'Я В УКРАЇНІ: НЕДОЛІКИ ОРГАНІЗАЦІї ТА РИЗИКИ РЕФОРМУВАННЯ
}

\author{
HEALTH CARE SYSTEM IN UKRAINE: DISADVANTAGES OF ITS \\ ORGANIZATIONAL STRUCTURE AND RISKS OF REFORMING
}

Неефективність використання ресурсів системи охорони здоров'я призводить до зниження стандартів медичного обслуговування та уповільнює інновачійний розвиток галузі. У той час як в розвинених краӥнах позначився тренд до розширення державних гарантій у сфері надання медичних послуг, в Украӥні їх доступність визначається платоспроможністю хворих в момент надання медичної допомоги, щуо $\epsilon$ однією 3 головних перепон до загального охоплення населення медичним обслуговуванням. Це послужило підгрунтям для розробки конщепщії реформування галузі в останні роки та здійснення перших практичних кроків до ї̈ втілення. Проте будь-яка реформа реалізовується в специфічних поточних умовах функціонування галузі $i$ повинна враховувати потенційні ризики від впроваджуваних заходів. У статті досліджено сучасні проблеми організації охорони здоров'я $i$ визначено потенційні ризики реформування галузі. Так, низький рівень доходів населення Украӥни за умови введення обов'язкових для всіх категорій населення співплатежів може мати наслідком: скорочення державних зобов'язань з надання медччних послуг, відмову частини населення від користування медичними послугами або їх найбільш вартісними видами, збільшення адміністративних витрат, порушення принщииу соціальної справедливості у доступі до медичної допомоги, зниження ефективності приватних ресурсів галузі, посилення сегрегаиії на ринку медичних послуг. При изьому відсутність доступу споживачів до повної інформації про якість надання послуг різними операторами цьього ринку разом із неможливістю для пацієнтів здійснити об'єктивну оцінку власної необхідності у тих чи інших медичних продуктах є суттєвими бар'єрами для формування здорового конкурентного середовища у галузі. Мінімізація зазначених ризиків потребує розробки та реалізації спеціальних політичних заходів, спрямованих на сприяння реалізації права на медичну допомогу найменш захищених верств населення.

Ключові слова: охорона здоров'я, медичне забезпечення, фінансування, реформування, ризики.

Inefficiency of using the resources of the health care system leads to a decrease in the standards of medical care and slows down the innovative development of the industry. While we can see the trend towards the expansion of state guarantees of medical services in developed countries, in Ukraine their availability is determined by the solvency of patients at the time of illness, which is one of the main obstacles to universal coverage with medical assistance. This leads to development of the concept of the industry reforming in recent years and triggered the first practical steps towards its implementation. However, any reform is implemented in specific current conditions and must take into account the potential risks from implemented activities. The article deals with current problems of health care organization and identifies the potential risks of its reforming. The low level of income of the population in Ukraine in case of introduction of mandatory co-payments can lead to: reduction of state obligation to provide medical services, partial denial of the population from the use of medical services or their most 
expensive types, increase in administrative costs, violation of the principle of social justice with regard to access to medical help, reduction in the efficiency of private resources of the industry, increase in segregation in the market of medical services. At the same time, the lack of consumers' access to complete information on the quality of full range of service provision suggested by different operators as well as the impossibility for patients to assess objectively their own need in certain medical products are essential barriers to the formation of a healthy competitive environment in this area. Minimization of these risks requires the development and implementation of special policy measures aimed at promoting the realization of the right to medical care for the most vulnerable segments of the population.

Key words: health care, medical provision, financing, reforming, risks.

Вступ. Питання реформування системи охорони постало перед країною 3 набуттям незалежності. Дослідженню проблем функціонування системи охорони здоров'я, фінансування цієї галузі та формування іiі нормативноправової бази присвятили свої наукові роботи В.Андрущенко, Й.Бескида, О.Василик, О.Вашев, О.Величко, В.Войцехівський, Б.Волос, Ю.Вороненко, В.Дем'янишин, В.Журавль, Д.Карамишев, С.Кондратюк, В.Лехан, 3.Лободіна, З.Надюк, Ю.Пасічник, А.Підаєв, Д.Полозенко, Я.Радиш, І.Радь, В.Рудий, Г.Слабкий, О.Тулай, М.Шевченко, С.Юрій. Однак в період, коли країна стоїть на порозі впровадження найбільшої соціально-економічної реформи за останні 25 років, і реформа ця вже має для своєї реалізації початкову нормативно-правову базу, особливої актуальності набувають дослідження, спрямовані на визначення потенційних ризиків іiі майбутнього реформування та розробку механізмів їх мінімізації. Це і визначило тематику представленої наукової роботи.

Головною проблемою системи охорони здоров'я в Україні $є$ низький рівень ефективності використання ресурсів. За розрахунками Всесвітньої організації охорони здоров’я (ВОО3), в 2014 р. витрати на охорону здоров'я в Україні були на рівні 7,1\% від ВВП, що $є$ середнім показником для країн європейського регіону [1] (за оцінкою Держстату в 2015 р. державні та приватні витрати разом склали 7,8\% ВВП країни) [2]. При цьому, до «утримання» системи охорони здоров'я залучено більше ніж 9 із 10 домогосподарств (у 2016 р. таких було 94\% [3]) і приватні джерела (кошти домогосподарств, роботодавців, некомерційних організацій, що обслуговують домогосподарства) складають більше половини ресурсів системи охорони здоров’я (50,9\% у 2015 р.) [2].

Водночас для країни, в якій право кожного на медичну допомогу $є$ одним 3 головних соціальних прав, частка домогосподарств, в яких хоч один 3 членів родини не зміг при потребі отримати медичну допомогу, придбати ліки або медичне приладдя, є надвисокою - 23,1\% в 2016 р. [3].

Характер залучення в медичну галузь більшої частини коштів домогосподарств (прямі платежі в момент отримання медичної допомоги) не дозволяє отримувачу послуг впливати на їхню якість і не сприяє втіленню принципу соціальної солідарності в розбудові національної системи охорони здоров'я. Всесвітня організація охорони здоров'я (ВО3) визначає залежність населення від прямих платежів в момент необхідності отримання медичної 
допомоги однією з головних перепон до загального охоплення населення країни медичною допомогою [4].

Частка приватних коштів в системі охорони здоров'я України не тільки є суттєвою, а й знаходиться в межах тенденції до щорічного зростання. Невпорядкованість приватних та державних механізмів породжує численні корупційні небезпеки та негативно позначається на функціонуванні національної економіки, що і стало підгрунтям для виявлення недоліків організації та визначення ризиків реформування системи охорони здоров'я в Україні.

Постановка завдання. Метою статті $\epsilon$ дослідження проблем організації охорони здоров'я в Україні, вироблення рекомендацій для усунення ризиків реформування галузі. Головними завданнями дослідження є: визначення останніх тенденцій в організації систем надання медичних послуг в розвинених країнах, встановлення передумов реформування системи охорони здоров'я в Україні, аналіз ризиків реформування вітчизняної системи медичного забезпечення, формулювання переліку практичних заходів, спрямованих на їх мінімізацію.

Методологія дослідження. Для реалізації поставлених завдань у роботі було використано наступні методи дослідження та аналізу емпіричних даних: структурно-функціональний аналіз, метод історичної аналогії, методи аналізу та синтезу та метод узагальнення.

Результати дослідження. У 2005 р. Всесвітня асамблея охорони здоров’я прийняла резолюцію, в якій закликала всі країни створити систему фінансування, що забезпечить все їхнє населення загальним доступом до всіх медико-санітарних послуг (включаючи лікування, реабілітацію, профілактику і заходи, спрямовані на формування здорового способу життя) та зможе гарантувати кожному громадянину, що користування медичними послугами не буде загрожувати економічному стану його домогосподарства $[5]$.

Сучасні системи охорони здоров'я в розвинених країнах пройшли довгий шлях розвитку від моделей охорони здоров'я без державного регулювання до моделей загального охоплення, що базуються на певній, історично притаманній конкретній країні, організаційно-фінансовій системі медичної допомоги. У процесі еволюції різні початково системи охорони здоров'я набували рис одна одної та запозичували одна у одної найбільш прогресивні елементи організації. Прагнучи повного охоплення населення медичними послугами і збільшення їх доступності для найбідніших верств, більшість систем охорони здоров'я розвинених країн набули гібридного характеру з акцентом на збільшення ролі держави в управлінні ними.

Отже, помітним трендом у розвитку медичної галузі в останнє десятиріччя $\epsilon$ соціалізація медичних послуг, тобто забезпечення соціальних гарантій держави та збільшення доступності медичної допомоги для широких верств населення завдяки проактивній діяльності держави 3 формування страхових пулів, перерозподілу ризиків між ними, управляння фінансами, 
формування держзамовлення та впливу на цінову політику медичних закладів та фармацевтичних компаній.

За будь-якої системи організації охорони здоров'я особливо гостро в умовах обмеженості ресурсів стоїть питання фінансування лікування хронічних захворювань, витратних методів лікування та діагностики. 3 одного боку, у вигляді прямих платежів такого роду витрати не здатні покрити більшість домогосподарств (не тільки вітчизняних, але й у будь-якій країні), 3 іншого - ці витрати нераціонально включати в системи гарантованих безоплатних медичних послуг, оскільки послуги високої вартості за необмеженості доступу ризикують стати головним джерелом нераціонального використання суспільних ресурсів. Проте, так чи інакше гарантом надання медичних послуг в таких випадках має виступати держава, головним завданням якої $\epsilon$ забезпечення їх доступності. Таким чином, для подібних методів лікування та діагностики повинні бути чітко визначені джерела фінансування та умови доступу, рівні для всіх громадян. Так, наприклад, витратна діагностика за допомогою методу МРТ повинна бути доступною в екстрених випадках для надання невідкладної допомоги, тоді як фінансування лікування онкологічних захворювань може відбуватися за спеціальною державною програмою або низкою програм, видатки на які $є$ захищеними статтями бюджету. В умовах страхової медицини фінансування витратних методів лікування та діагностики повинно забезпечуватися за рахунок вирівнювання ризиків між страхувальниками, що забезпечують загальне охоплення населення обов'язковим медичним страхуванням.

Навіть в країнах з провідною роллю ринкових механізмів регулювання галузі охорони здоров'я високовитратні методи або випадки лікування фінансуються за рахунок бюджету. Так, наприклад, уряди Нідерландів та Швейцарії видатки, що $\epsilon$ надто обтяжливими для страхової системи, покривають коштами держави згідно з встановленою процедурою розподілу державного фінансування між всіма закладами, що беруть участь у наданні безоплатної медичної допомоги [6]. Після того як застосування ринкових механізмів у розбудові системи охорони здоров'я у Китаї призвело до збільшення частки прямих платежів до 60\% від усіх видатків на охорону здоров’я у 2000 р., уряд країни проголосив курс на реформу галузі, кінцевою метою якої визначено ефективне та доступне медичне обслуговування для всіх громадян незалежно від місця проживання [7].

Водночас, у доповіді ВООЗ наголошується, що навіть країни з високим доходом не можуть забезпечити охоплення всього населення всім спектром безкоштовних медичних послуг. Якщо йдеться про бюджетне фінансування без залучення коштів на умовах передплати, то завжди доводиться шукати баланс між часткою населення, яку охоплює таке фінансування, спектром послуг, що доступні в межах нього, та часткою цих державних витрат в усіх ресурсах, спрямованих на утримання системи охорони здоров'я [4].

Багато країн 3 трансформаційною економікою у реформуванні своїх систем охорони здоров'я пішли шляхом означення обсягів державних зобов'язань у цій сфері. Так, у Білорусі всі види медичних послуг, що 
надаються громадянам державою безкоштовно, та їхній обсяг означені у «Територіальних програмах державних гарантій надання громадянам безоплатної медичної допомоги» [8; 9]. Так само у Російській Федерації Програмою державних гарантій забезпечення громадян РФ безоплатною медичною допомогою було встановлено перелік видів, форм та умов надання безоплатної медичної допомоги, а також захворювань та медичних станів, медична допомога при яких надається безоплатно, середні нормативи обсягу медичної допомоги та фінансових видатків на їі надання, а також структуру тарифів на медичні послуги та способи їх оплати [10]. Таким чином, в цих країнах було законодавчо введено механізм співплатежів, який (в різному вигляді) існує в усіх розвинених країнах.

Крім того, більшість пострадянських країн взяли курс на підвищення фінансової автономності медичних закладів. Головна ідея реалізації фінансово-організаційних заходів, спрямованих на досягнення цієї мети надати можливість їх керівникам діяти в інтересах пацієнтів та у відповідності до стратегічних цілей розвитку підзвітної організації. При цьому доступ до ресурсів, призначених медичному закладу, має бути таким самим легким, як і доступ до нині діючих благодійних фондів.

Найбільш перспективним напрямом розвитку систем охорони здоров'я західних країн $\epsilon$ розвиток реактивності, тобто такої гнучкості в організації їхньої роботи, яка б забезпечувала здатність мінімізувати як внутрішні соціально-демографічні загрози, пов'язані із старінням населення (зростання частки літніх людей, збільшення терміну життя у похилому віці, скорочення можливостей для наповнення страхових фондів), так і зовнішні ризики для суспільного здоров'я, викликані збільшенням інтенсивності міграційних потоків - поширення екзотичних хвороб, епідемій та пандемій.

Якщо система охорони здоров'я не має високого рівня адаптивності до соціальних умов, що постійно змінюються під швидкою дією внутрішніх та зовнішніх загроз, вона, не задовольняючи потреби населення у медичних товарах та послугах, стане найслабкішою ланкою у забезпеченні національної безпеки. Навіть у країнах з пристойними місцями у рейтингу ВОО3[11] більшість населення визнає необхідність у вдосконаленні системи надання медичної допомоги. Так, більше половини жителів Канади $(55 \%)$, Нової Зеландії (52\%), Швеції (51\%) та жителів Сполучених Штатів (52\%) заявили, що система охорони здоров'я їхньої країни потребує докорінних змін. На додачу до цього, $23 \%$ жителів Сполучених Штатів заявили, що їхня система охорони здоров'я має бути повністю перебудована [12]. Цей факт $\epsilon$ яскравим свідченням того, що населення цієї країни свідоме економічних, організаційних та фінансових проблем існуючої в ній системи надання медичних послуг.

Оскільки система охорони здоров'я $є$ суспільним благом, то іiі ефективність визначається не лише тим, наскільки раціонально (у перерахунку на товари та послуги) використовуються іiі ресурси, а й тим, наскільки існуючий механізм іiі фінансування дозволяе досягати вищих суспільних цілей: забезпечення доступності медичного обслуговування, 
послаблення нерівності доступу до ресурсів охорони здоров'я, відповідність системи нагальним потребам населення у лікуванні та догляді, збільшення консолідації суспільства через солідарне фінансування, підвищення рівня соціальної інклюзії.

Виходячи 3 цього, показники прогресивності та ефективності впроваджуваних реформ повинні включати в себе кількісні індикатори, що свідчать про збільшення доступності медичних послуг, підвищення їхньої якості та покращення умов роботи лікарів та медперсоналу. До таких можуть бути віднесені:

- скорочення частки видатків бідних верств населення на медичні послуги та медикаменти;

- збільшення доступності вузькоспеціалізованої медичної допомоги та вартісної діагностики;

- збільшення звернень до медиків за спеціалізованою допомогою та підвищення рівня вакцинації;

- скорочення смертності від захворювань, лікування яких є вартісним;

- зменшення захворюваності та збільшення тривалості життя;

- підвищення рівня задоволеності пацієнтів;

- зростання доходів медиків.

Ухвалений Верховною Радою 19 жовтня 2017 р. Закон України «Про державні фінансові гарантії надання медичних послуг та лікарських засобів» $\epsilon$, по суті, першим кроком до введення поширеного в усьому світі механізму співплатежів за медичні послуги та товари медичного призначення. У цілому ВООЗ оцінює роботу цього механізму позитивно, оскільки він сприяє додатковому залученню коштів у систему охорони здоров'я, підвищуе ефективність їх використання і знижує невиправдане надмірне споживання ресурсів системи [4].

Тим не менше, в нинішніх умовах в Україні введення співплатежів в системі охорони здоров'я може викликати низку ризиків:

- відмова частини населення від користування платними або частково оплачуваними медичними послугами, що призведе до погіршення стану здоров'я населення, збільшення числа людей 3 хронічними захворюваннями;

- порушення принципу справедливості у доступі до медичної допомоги за умови, що рівень платежів та доплат буде надто високим відносно середніх доходів населення;

- збільшення адміністративних витрат на налагодження і підтримку роботи системи пільг, знижок та виключень, спрямованої на забезпечення доступності медичних послуг для соціально незахищених верств населення;

- зниження ефективності поточних неофіційних витрат на медичні послуги, які несуть домогосподарства у випадку, якщо держава не встановить високих стандартів медичного обслуговування або не зможе забезпечити ефективний контроль над коштами, які будуть 
приходити в систему охорони здоров'я за офіційними каналами після проведення реформи;

- посилення сегрегації на ринку медичних послуг у випадку якщо приватні та неприбуткові лікарні та амбулаторії не будуть допущені до надання послуг (з подальшим державним відшкодуванням їхньої вартості) на тих самих умовах, на яких будуть діяти державні та муніципальні заклади;

- ризик скорочення державних зобов’язань з надання найбільш соціально значимих послуг - охорона материнства, дитинства, медичне обслуговування інвалідів та осіб похилого віку.

Крім того, очікується, що значних фінансових ресурсів потребуватиме оновлена система державного управління масштабною галуззю, 3 особливостями, що не сприяють «самоналогодженню» процесів функціонування. 3 одного боку, між лікарняними закладами повинна бути конкуренція, 3 іншого - в жодному разі не можна сподіватися, що впровадження «ринкових механізмів» у галузі охорони здоров'я автоматично призведе до підвищення ефективності використання коштів. Ринок медичних послуг ніколи не буде «ринком» у загальному розумінні цього слова через те, що споживач на «ринку» не має повної інформації про якість надання медичних послуг та конкурентних перевагах медичних продуктів особисто для нього, а вибір медичних закладів як постачальників медичних послуг для більшості населення обмежений територіальним фактором, що є таким самим вагомим аспектом доступності, як і прийнятна вартість.

Для мінімізації цих ризиків пропонується здійснення наступних заходів державної політки.

1. У відповідності до рекомендацій ВОО3 [4] доля прямих платежів населення повинна бути знижена до 15 - 20\% від загальних обсягів фінансування системи охорони здоров'я з метою зниження ризику бідності для населення, яке в певний момент часу потребує медичної допомоги.

2. Упровадження механізмів послаблення негативного впливу співплатежів на користування медичними послугами представниками незахищених верств населення (як то: система пільгових співплатежів для осіб $з$ низькими доходами, створення та наповнення фінансових пулів, спрямованих на медичне забезпечення неплатоспроможних осіб, встановлення максимальних сум річних видатків на співплатежі для осіб 3 хронічними захворюваннями).

3. Розробка та запровадження механізму державно-приватного партнерства в організації роботи медичних закладів 3 метою підвищення ефективності використання ресурсів. Економічний аналіз фінансових результатів діяльності медичних закладів, що беруть участь в проектах державно-приватного партнерства в різних країнах, свідчить про те, що при застосуванні цього методу організації їхньої роботи відбувається підвищення якості медичного обслуговування одночасно зі зниженням витрат на медичні послуги (економія суспільних ресурсів сягає 10\%) [13; 14$].$ 
4. Забезпечення рівності доступу населення до медичних послуг для реалізації принципу соціальної справедливості. Таким чином, з солідарної системи повинно бути виведене користування спеціальними медичними закладами, доступ до яких надається за категоріальною ознакою. Для збереження пільг для тих категорій громадян, які користуються нині медичним обслуговуванням на спеціальних умовах, повинно бути забезпечене професійне страхування.

5. Запровадження моніторингу ефективності реформи охорони здоров'я за допомогою кількісних індикаторів, що свідчать про збільшення доступності медичних послуг, підвищення їхньої якості та покращення умов роботи лікарів та медперсоналу.

Висновки. За ознаками формування джерел покриття фінансових витрат на лікування для населення і відповідальності лікарів за результати своєї професійної діяльності нинішня система охорони здоров'я подібна до притаманних найбіднішим країнам натуральних моделей організації охорони здоров'я, в яких доступ до медичної допомоги обмежується фінансовою спроможністю хворих, а стосунки між лікарями та пацієнтами не підлягають повній правовій впорядкованості.

Реформа системи охорони здоров'я, що нині впроваджується в Україні, відповідає головним тенденціям розвитку цієї галузі в розвинених країнах: забезпечення загального охоплення населення найбільш необхідними видами медичної допомоги, збільшення фінансової автономності лікарняних закладів, диверсифікація джерел фінансування галузі, підвищення рівня іiі адаптивності. Разом з тим, усунення потенційних ризиків, які може нести в собі впроваджувана реформа, потребує реалізації низки заходів соціальної політики, спрямованих на збереження доступності медичних послуг для найменш захищених верств населення. Практичне значення представленої наукової роботи обумовлене розробкою та обгрунтуванням таких заходів. Водночас іiі наукова новизна полягає в поглибленні теоретико-методичних засад дослідження соціальної сфери та розробленні практичних рекомендацій щодо подальшого реформування медичної галузі. Актуальність і спрямованість подальших досліджень у цьому напрямі буде визначатися першими соціально-економічними результатами від впровадження реформи охорони здоров'я в найближчі роки.

\section{Лiтература:}

1. Total health expenditure as proportion of GDP (WHO estimates) // Health for all. European Health Information Gateway / World Health Organization. URL: https://gateway.euro.who.int/en/hfa-explorer/\#9cym2WKC80 (дата звернення: 02.03.2018) 2. Національні рахунки охорони здоров’я (НРОЗ) України у 2015 році: Статистичний бюлетень / Держстат URL: www.ukrstat.gov.ua/druk/publicat/kat_u/2017/bl/02/bl_nroz15.zip (дата звернення: 02.03.2018) 3. Витрати і ресурси домогосподарств України у 2016 р. / Держстат України. URL: www.ukrstat.gov.ua/druk/publicat/kat_u/2017/zb/07/zb_vrdu2016pdf.zip (дата звернення: 02.03.2018) 
4. Доклад о состоянии здравоохранения в мире, 2010 г. Финансирование систем здравоохранения: путь к всеобщему охвату населения медико-санитарной помощью / Всемирная организация здравоохранения. URL: http://www.who.int/whr/2010/ru/ (дата звернення: 07.03.2018)

5. Resolution WHA58.33. Sustainable health financing, universal coverage and social health insurance / WHO. URL: http://apps.who.int/medicinedocs/documents/s21475en/s21475en.pdf (дата звернення: 07.03.2018)

6. Funding Health Care: Options for Europe / Edited by E. Mossialos, A. Dixon, J. Figueras, S. Kutzin. - Buckingham, PA: Open Univesity Press, 2002. 309 p. URL: http://www.euro.who.int/_data/assets/pdf_file/0003/98310/E74485.pdf (дата звернення: 11.03.2018)

7. Meng Q, Tang S. Universal coverage of health care in China: challenges and opportunities. World health report 2010 background paper, no.7. URL: http://www.who.int/healthsystems/topics/financing/healthreport/whr_background/en (дата звернення: 14.03.2018)

8. О мерах по внедрению системы государственных социальных стандартов по обслуживанию населения республики: Постановление Совета Министров Республики Беларусь от 30 мая 2003 г. № $724 . \quad$ URL: http://pravo.levonevsky.org/bazaby09/sbor41/text41591.htm (дата звернення: 10.03.2018)

9. О некоторых вопросах государственных минимальных социальных стандартов в области здравоохранения: Постановление Совета Министров Республики Беларусь от 29 марта 2016 № 259. URL: www.minzdrav.gov.by_normativnye_prikazy (дата звернення: 10.03.2018)

10. О программе государственных гарантий бесплатного оказания гражданам медицинской помощи на 2017 год и на плановый период 2018 и 2019 годов: Постановление Правительства Российской Федерации от 19 декабря 2016 г. № 1403. URL: http://klinikabudzdorov.ru/upload/patients_rights/gos_garantii_2017.pdf (дата звернення: 09.03.2018)

11. The World health report 2000: health systems: improving performance. Geneva: World Health Organization 2000. 206 p. URL: http://www.who.int/whr/2000/en/whr00_en.pdf (дата звернення: 10.03.2018)

12. International Health Policy Surveys / The Commonwealth Fund. URL: http://www.commonwealthfund.org/topics/current-issues/international-surveys (дата звернення: 10.03.2018)

13. Кузнецов И.В. Зарубежный опыт государственно-частного партнерства (США, Европа, Канада). Экономические науки. 2012. № 8 (93). С. 196-201.

14. Варнавский В.Г. Государственно-частное партнерство в здравоохранении: международный опыт. Управление здравоохранением. 2010. № 1. С. 9-16. 